\title{
Indigenous Doctors, Health and Sporting Activities in Indochina before 1941
}

\author{
Brice Fossard* \\ Research fellow to the International History Center and Political Studies on Globalization, Lausanne, France
}

*Corresponding author: Brice Fossard, Research fellow to the International History Center and Political Studies on Globalization, Lausanne, France

\begin{tabular}{|c|c|}
\hline ARTICLE INFO & ABSTRACT \\
\hline Received: 凿 June 03, 2019 & \multirow{2}{*}{$\begin{array}{l}\text { Citation: Brice Fossard. Indigenous Doctors, Health and Sporting Activities in Indochina } \\
\text { before 1941. Biomed J Sci \& Tech Res 18(5)-2019. BJSTR. MS.ID.003200. }\end{array}$} \\
\hline Published: 呲 June 11, 2019 & \\
\hline
\end{tabular}

\section{Opinion}

French Indochina was occupied by the Japanese army during the Second World War and the vice-admiral Decoux became governor general. He tried to implement a new political program above all for the local youth. I have been working for five years about this topic [1] and most of the time when I read one article or a book [2] I discover that Vichy was the climax for sport policies and health activities. I argue that it is partly wrong, and I would like to demonstrate that Vichy could not create its policies without the legacy of the Third republic [3]

According to Jean Decoux. [...] the local youth who before was reluctant to practice or unaware of the physical exercises are gradually turning to physical education. [...] one should use this impetus to set up a proper physical education promoting order and discipline and a harmonious racial development. It is necessary to integrate physical education into the school curriculu [4].

Decoux promoted Physical Education at school as if he was the inventor of this action in Indochina. It's wrong because since 1917 Albert Sarraut has complemented the school curriculum by adding some lessons about physical education for elementary and primary schools: schoolboys had to practice Moral and Physical Education such as running, playing with balls or training like child soldiers. In addition, two years later Nguyen Qui Toan opened his Physical educational school in Hanoi: he was sent to France to study and discovered one of the reasons of the French superiority: sporting and physical activities. In 1913 he trained in Reims at the "Collège des Athlètes" and came back to Hanoi in order to face his country's challenges. At the very beginning this School was very famous and succeeded in attracting one hundred and fifty-two children [5]. Then, this school was a model for many societies in Indochina. In Cochinchina now, many Indochinese doctors took part to this acculturation process [6] by spreading the ways to improve children's health or to prevent diseases in the early 1920s. For instance, Pham Van Ngoi used his leadership and his athletic training experience to convince the audience to follow the example of the Western elite citizens [7]. His colleague Tran Van An was the president of the 'Cercle Annamite Sportif' in Saigon, the most powerful Annamite tennis club there.

In Saigon, the Regional Center for Physical Instruction, a military school, was opened in 1923. Then, the other capitals had their own similar school. Each center was training every year around one hundred schoolteachers. So we can conclude that physical education, sports activities and health advice were spreading for a long time before the Second World War. The newspapers during the Interwar issued many articles about this topic and asserted the same ideas: "The French colonization is characterized by a positive transformation of the indigenous population's physical and spiritual health (....). This evolution was made possible by the practice of sport activities and above all because of physical education. And we can claim beyond doubt that thousands of Annamites have been saved from rickets, from tuberculosis among other afflictions thanks to an elementary physical hygiene that has been methodically and regularly put into practice for some years [8].

This journalist underlined that the main State action was to improve health. In reality these activities were just practiced 
by around ten percent of the young Indochinese people, those who were sent to school. These young elite members had the opportunity to belong to sport associations like the French colonials. Most of these players belonged to the local urban elite but in the 1930's some peasants or workers rode bicycles or played football. So, these activities spread into the countryside too. It's rather easy to demonstrate that sport activities were developed from 1920 to 1940 thanks to the private associations and the colonial administration. For instance, since 1923 the civil and military authorities organized each year in Cochinchina and Cambodia three or four competitions (athletics, football, tennis). In addition, Pierre Pasquier, the Governor General, created the "First Indochina Cup" for tennis in 1929 and a second one appeared in 1936 to commemorate the opening of the first Indochinese railway. There were between three ou four football cups in each territory. Moreover, one could easily find much medical information about the training and sport injuries into the newspapers; so thanks to this advice, Indochinese adults were able to take care of children who loved playing football or riding bicycles.

To conclude I can say that the French administrative action enabled some Indochinese elite members to improve their health. The French Republic was not a minor element into the development of sporting activities thanks to the key role played by the Indochinese doctors. These latter founded many associations and spread advice to be in good health for many thousands of persons before 1941.

\section{ISSN: 2574-1241}

DOI: 10.26717/BJSTR.2019.18.003200

Brice Fossard. Biomed J Sci \& Tech Res

CC (P) This work is licensed under Creative

Submission Link: https://biomedres.us/submit-manuscript.php

\section{References}

1. Brice Fossard (2017) Sports, Scouting and Indochinese elites. From colonial separatism to national liberation (1858-1945) Ph. D. Universities of Lausanne and Paris1 Panthéon Sorbonne.

2. Anne Raffin (2008) Youth mobilization in Vichy Indochina and its legacies, 1940-1970. In: Chizuru Namba (2012) (Eds.). French and Japanese in Indochina (1940-1945), (Paris: Karthala); Christopher Goscha, The Penguin History of Modern Vietnam.

3. This new culture of the body was just improved by Decoux's regime.

4. (1941) National Archives of Vietnam (Hô Chi Minh City), center No. 2, II A 45 / 182-5, educational orientation and youth work in the various provinces.

5. (1918) National Archives of Vietnam (Hanoi), centre ${ }^{\circ} 1$, Hanoi, RST R62 8485 'règlement de l'école d'éducation physique de Hanoi fondée en par Nguyen Quy Toan, professeur au collège du Protectorat, sd.'

6. Melville J Herskovits, Robert Redfield, Ralph Linton (1936) Memorandum for the study of acculturation. American Anthropologist 38, no. 1. 149 This 'phenomenon that results when groups of individuals from different cultures come into continuous firsthand contact, with subsequent changes in the original cultural patterns of either or both groups'.

7. (1923) National Library of France.

8. Melville J Herskovits, Robert Redfield, Ralph Linton (1938) l'Education physique dans les écoles de Cochinchine. Memorandum for the study of acculturation, American Anthropologist 38, no. 1, (1936): 149 This phenomenon that results when groups of individuals from different cultures come into continuous first-hand contact, with subsequent changes in the original cultural patterns of either or both groups.

9. (1923) National Library of France.

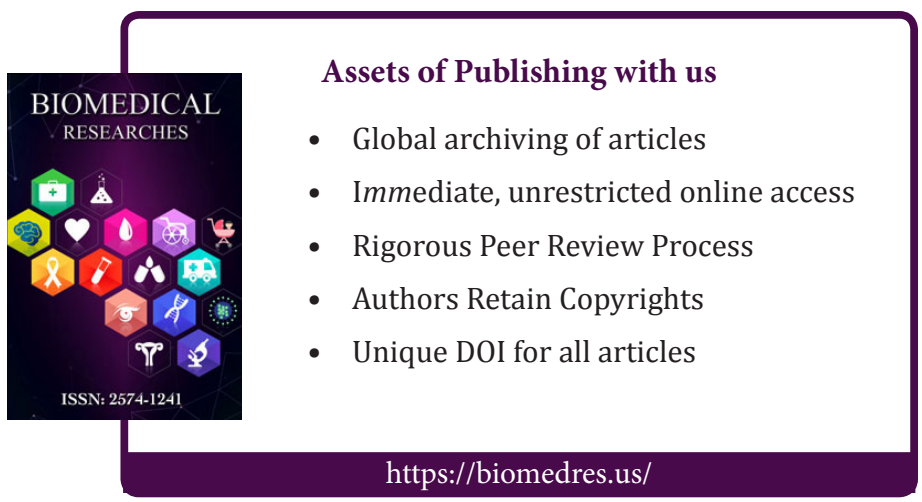

